\title{
Effect of bulb set girth and plant density on production of green bunch onion (Allium cepa L.) under rain-fed conditions at Blue Nile State, Sudan
}

\begin{abstract}
Experiments were carried out at Damazin Research Station farm during kharif season 2016 and 2017, to evaluate the effects of bulb set girth and plant density on growth, yield and characters of onion under rain-fed condition. Treatments include three factor of factorial combinations of two bulb set size girth (1-2 and 2-3 cm), intra-row spacing vis 7.5 and $10 \mathrm{~cm}^{2}$ and number of rows ridges ${ }^{-1}$ (two and three rows ridges ${ }^{-1}$ ). Results show that bulb set girth and plant density was effects on growth, yield and quality of onion. Results showed that The greatest yield tons ha $^{-1}$ was obtained by large set when grown at $10 \mathrm{~cm}$ intra-row spacing three rows ridges ${ }^{-1}$ in both seasons.
\end{abstract}

Keywords: plant density, bulb set size girth, intra-row spacing, kharif
Volume 2 Issue 6 - 2018

\author{
Adlan MA Adlan,' Aisha AM Ali ,'2 Faiha IM \\ Hassan,' Eisa YA' \\ 'Damazine Research Station, Sudan \\ ${ }^{2}$ Shambat Research Station, Sudan
}

\begin{abstract}
Correspondence: Adlan MAAdlan,Agricultural Research Corporation, Damazine Research Station, Sudan, Email
\end{abstract} adlan.m.a.2015@gmail.com

Received: December 03, 2018 | Published: December 31, 2018

\section{Introduction}

Onion (Allium cepa $\mathrm{L}$ ) is one of the oldest crops known to mankind and consumed worldwide. It is a member of the family Alliaceae and believed to originate and is central Asia Kukanoor. ${ }^{1}$ It is ranks second in area and third in production of the total vegetable in the world. The leading onion production countries are China, India, United State, Turkey and Pakistan Shaheen et al. ${ }^{2}$ They have high mineral and organic contents essential for human health Raj and Yadav. ${ }^{3}$ Therefore, onion is a commonly used ingredient in recipes. All the plant parts are edible, but the bulbs and the lower stem sections are the most popular as seasonings or as vegetables in stews Moard. ${ }^{4}$ So in some countries such as Bangladesh as much as $30 \%$ of the bulb crop is produced by onion set Rabinowith and Currah. ${ }^{5}$ In Sudan onion is classified as the most important and popular vegetable crop and is production in all regions of the country Abdelaziz. ${ }^{6}$

The diameter of the set is the primary factor that affects bulb or flower stalk production. A large onion set produces flowering stalks more rapidly than a small one. Yamaguchi ${ }^{7}$ reported that the ideal size of a set should be $1.5-2.0 \mathrm{~cm}$ in diameter. Bulbs greater than $2.5 \mathrm{~cm}$ in diameter become vernalized at low temperature and are prone to bolting.

To optimize onion productivity, full package of information is required Lemma and Shimeles. ${ }^{8}$ Plant population needs to be optimized. The optimum use of spacing or plant population has dual advantages Geremew et al. ${ }^{9}$ It avoids strong competition between plants for growth factors such as water, nutrient and light. In addition optimum plant population enables efficient use of available cropland without wastage.

In Sudan the main season for production onion was winter season from late October to June after this period markets were used storage bulb, east of Sudan which have a cold climate, sowing date and crop harvest are in July and at December, respectively. Occasionally, in period from August to November, there is a lack of onion bulbs in Sudan markets caused by a short shelf life and lack of optimal storage conditions. In this period, to compensate, green bunch onions are frequently used. Onion set, i.e. a small bulb, should be used for early production of green or bulb onions because early stages of growth and development of onion seedling are very slow and require considerable time. No research has been done on the production of green bunch onion under rain-fed conditions in the Blue Nile State. The present study was undertaken to evaluate the effects of bulb set size and plant density on growth, yield and quality of onion under rain-fed conditions in the Blue Nile State.

\section{Materials and methods}

Experiments were carried out at farm of Damazin Research Station during kharif season of 2016 and 17 in order to evaluate the effects of bulb set girth and plant density on growth, yield and quality of onion under rained fed condition. Treatments include three factor of factorial combinations of two set girth girth $(1-2$ and $2-3 \mathrm{~cm})$, intrarow spacing vis 7.5 and $10 \mathrm{~cm}$ and number of rows ridges ${ }^{-1}$ (two and three rows ridges ${ }^{-1}$ ) produced population $(333,250,500$ and 375 thousand plants $\mathrm{ha}^{-1}$ ). Production of sets were carried out at farm of Shambat Research Station during winter season of 2015/16 and 2016/17. The land was first disc harrowed and then divided into raised beds $80 \mathrm{~cm}$ wide the experimental units area three ridges 3 $\mathrm{m}$ long $\left(7.2 \mathrm{~m}^{2}\right)$. Sowing dates were on $29^{\text {th }}$ July and $5^{\text {th }}$ august over two seasons respectively, while the $8^{\text {th }}$ treatments were arranged in a split-split-plot design (SSBD) with 3 replications, bulb set girth $(\mathrm{cm})$ in whole plots, no. of rows ridges ${ }^{-1}$ in sup-plots and intra-row spacing $(\mathrm{cm})$ in sup- sup-plots . Hand weeding and pest control were used when necessary. The data collected included growth, yield parameters and bulb characters of onion. Five plants were taken randomly to measured growth parameters at the time of harvest include plant length. Yield parameters at the time of harvest include number and weight. Bulb characters of onion parameters were measured at the time of harvest and they included Percentage of doubling $\%$ and mean pulp girth $(\mathrm{cm})$. The data were subjected to ANOVA using the GenStat computer package. ${ }^{10}$

\section{Results}

Figure 1 shows meteorological data of rainfall $(\mathrm{mm})$ at both seasons in Damazin Research Station. Rainfall recorded in season 2017 was higher than that of 2016 and covered a long period. 


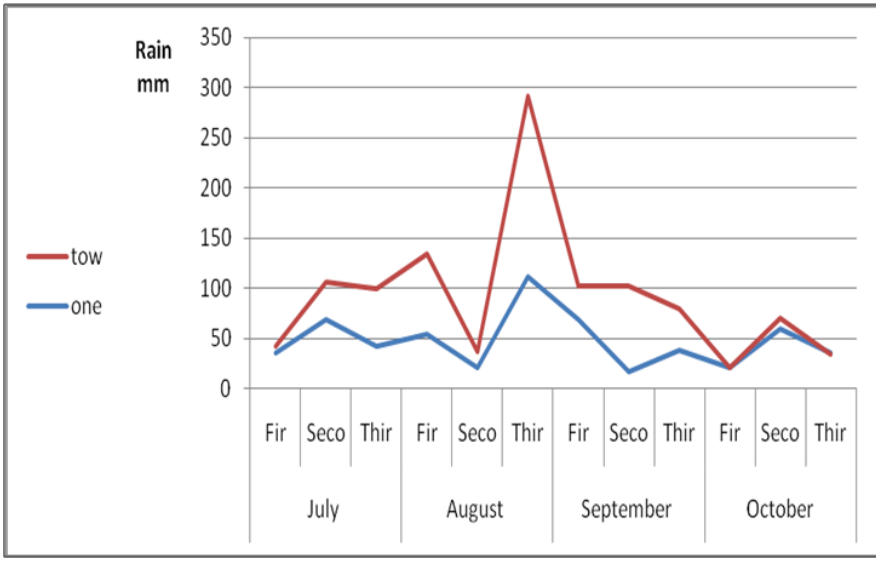

Figure I Metrological data of rainfall $(\mathrm{mm})$ at two seasons in damazin research station ministry of agriculture and natural resource at the blue nile state.

Table 1 shows that plant height $(\mathrm{cm})$ was effected by number of rows ridges ${ }^{-1}$ in both seasons and by Set size $(\mathrm{cm})$ just in season one, while was not affected by other factor and interaction of them. The greatest plant height was obtained by three rows ridges ${ }^{-1}$ in both seasons, Set girth $(2-3 \mathrm{~cm})$ in season one.

Table 2 shows that number of bulb ha-1 effected by rows ridges ${ }^{-1}$ and interaction of rows ridges ${ }^{-1} \mathrm{X}$ intra-row spacing in both seasons and by intra-row spacing $(\mathrm{cm})$ in season one, while in season two was affected by interaction of Set size $(\mathrm{cm}) \mathrm{X}$ no. rows ridges ${ }^{-1}$. The greatest number of bulb ha ${ }^{-1}$ was obtained by three rows ridges ${ }^{-1}$, set girth $(2-3 \mathrm{~cm}) \times 10$ intra-row spacing $\mathrm{cm}$ in both seasons, while in season two was obtained by interaction of set girth $(1-2 \mathrm{~cm})$ with three rows ridges ${ }^{-1}$.

Table 3 shows that Percentage of doubling \% was effected by set size in both seasons, number of rows ridges ${ }^{-1}$ in season two and intrarow spacing $(\mathrm{cm})$ in season one. On other had Percentage of doubling $\%$ was effected by interaction of Set size $(\mathrm{cm}) \mathrm{X}$ no. of rows, Set size $(\mathrm{cm}) \mathrm{X}$ intra-row spacing $(\mathrm{cm})$ in season one and by rows ridges ${ }^{-1}$ $\mathrm{X}$ intra-row spacing $(\mathrm{cm})$ in both seasons. The lowest Percentage of doubling \% was obtained when grown set girth $(1-2 \mathrm{~cm})$ and high population.

Table I Effects of set girth $(\mathrm{cm})$, number of rows ridges-I, intra-row spacing $(\mathrm{cm})$ and their interaction on plant height $(\mathrm{cm})$ over two seasons

\begin{tabular}{|c|c|c|c|c|c|c|c|}
\hline \multirow{3}{*}{ No. of rows ridges ${ }^{-1}$} & \multirow{3}{*}{$\begin{array}{l}\text { Intra-row } \\
\text { spacing }(\mathrm{cm})\end{array}$} & \multicolumn{3}{|c|}{ Season one } & \multicolumn{3}{|c|}{ Season two } \\
\hline & & \multicolumn{6}{|c|}{ Set girth (cm) } \\
\hline & & $2-3$ & $1-2$ & Mean & $2-3$ & $1-2$ & Mean \\
\hline \multirow[t]{2}{*}{2} & 7.5 & 47.4 & 46.4 & 46.9 & 46.4 & 51.1 & 48.8 \\
\hline & 10 & 50.0 & 45.7 & 47.9 & 43.1 & 46.7 & 44.9 \\
\hline Sp. mean & & 48.7 & 46.1 & 47.4 & 44.8 & 48.9 & 46.9 \\
\hline \multirow[t]{2}{*}{3} & 7.5 & 50.9 & 51.4 & 51.2 & 48.9 & 48.8 & 48.8 \\
\hline & 10 & 51.5 & 48.4 & 50.0 & 45.7 & 47.7 & 46.7 \\
\hline Sp. mean & & 51.2 & 49.9 & 50.6 & 47.3 & 48.2 & 47.8 \\
\hline Mean & & 50.0 & 48.0 & 49.0 & 46.4 & 51.1 & 47.3 \\
\hline \multicolumn{8}{|c|}{ Statistics } \\
\hline & & Sig. & $\mathrm{SE} \pm$ & $\mathrm{CV} \%$ & Sig. & $\mathrm{SE} \pm$ & $\mathrm{CV} \%$ \\
\hline \multicolumn{2}{|l|}{ Set size $(\mathrm{cm})$} & $*$ & 0.6 & & NS & - & \\
\hline \multicolumn{2}{|l|}{ rows ridges ${ }^{-1}$} & $* * *$ & 0.6 & & $*$ & 1 & \\
\hline \multicolumn{2}{|l|}{ intra-row spacing $(\mathrm{cm})$} & NS & - & & NS & - & \\
\hline \multicolumn{2}{|c|}{ Set size $(\mathrm{cm}) \mathrm{X}$ no. of rows } & NS & NS & 6.9 & NS & & 6.4 \\
\hline \multicolumn{2}{|c|}{ Set size $(\mathrm{cm}) X$ intra-row spacing $(\mathrm{cm})$} & NS & NS & & NS & & \\
\hline \multicolumn{2}{|c|}{ rows ridges ${ }^{-1} \mathrm{X}$ intra-row spacing $(\mathrm{cm})$} & NS & NS & & NS & & \\
\hline \multicolumn{2}{|l|}{ All interaction } & NS & NS & & NS & & \\
\hline
\end{tabular}

Table 4 shows that pulp girth $(\mathrm{cm})$ was effected by rows ridges ${ }^{-1}$ in both season, Set size $(\mathrm{cm})$ and intra-row spacing $(\mathrm{cm})$ in season one and two respectively. While was effected by interaction of rows ridges $^{-1} \mathrm{X}$ spacing in both seasons, Set size $(\mathrm{cm}) \mathrm{X}$ rows ridges ${ }^{-1}$ and Set size $(\mathrm{cm}) \mathrm{X}$ spacing in season one and two respectively. The greatest pulp girth $(\mathrm{cm})$ was obtained when grown set girth $(2-3 \mathrm{~cm})$ and low population.
Table 5 shows that yield tons ha $^{-1}$ was effected by all factors and their interaction in both seasons except number rows ridges ${ }^{-1}$ in season two and interaction of Set size $(\mathrm{cm}) X$ intra-row spacing $(\mathrm{cm})$ in season one. The greatest yield tons $\mathrm{ha}^{-1}$ was obtained by set girth $(2-3 \mathrm{~cm})$ when grown at $10 \mathrm{~cm}$ intra-row spacing three rows ridges ${ }^{-1}$ $\left(375,000\right.$ plants $\left.\mathrm{ha}^{-1}\right)$ in both seasons. 
Table 2 Effects of set girth $(\mathrm{cm})$, number of rows ridges ${ }^{-1}$, intra-row spacing $(\mathrm{cm})$ and their interaction on number of bulb ha ${ }^{-1}$ over two seasons

\begin{tabular}{|c|c|c|c|c|c|c|c|}
\hline \multirow{3}{*}{ No. of rows ridges } & \multirow{3}{*}{$\begin{array}{l}\text { Intra-row } \\
\text { spacing }(\mathbf{c m})\end{array}$} & Seasol & & & Seaso & & \\
\hline & & \multicolumn{6}{|c|}{ Bulb set girth (cm) } \\
\hline & & $2-3$ & $1-2$ & Mean & $2-3$ & $1-2$ & Mean \\
\hline \multirow[t]{2}{*}{2} & 7.5 & 260.1 & 274.3 & 267.2 & 263.2 & 314.6 & 288.9 \\
\hline & 10 & 306.3 & 330.6 & 318.4 & 269.4 & 322.2 & 295.8 \\
\hline \multicolumn{2}{|l|}{ Sp. mean } & 213.9 & 218.1 & 216.0 & 256.9 & 306.9 & 281.9 \\
\hline \multirow[t]{2}{*}{3} & 7.5 & 369.4 & 268.4 & 318.9 & 344.4 & 383.1 & 363.8 \\
\hline & 10 & 447.2 & 343.8 & 395.5 & 393.1 & 418.8 & 405.9 \\
\hline \multicolumn{2}{|l|}{ Sp. mean } & 291.7 & 193.1 & 242.4 & 295.8 & 347.4 & 321.6 \\
\hline \multicolumn{2}{|l|}{ Mean } & 314.8 & 271.4 & 293.1 & 303.8 & 348.8 & 326.3 \\
\hline \multicolumn{8}{|c|}{ Statistics } \\
\hline & & Sig. & $\mathrm{SE} \pm$ & $\mathrm{CV} \%$ & Sig. & $\mathrm{SE} \pm$ & $\mathrm{CV} \%$ \\
\hline \multicolumn{2}{|l|}{ Set size $(\mathrm{cm})$} & NS & - & & NS & - & \\
\hline \multicolumn{2}{|l|}{ rows ridges ${ }^{-1}$} & * & 15 & & * & 12 & \\
\hline \multicolumn{2}{|c|}{ intra-row spacing $(\mathrm{cm})$} & * & 14 & & NS & - & \\
\hline \multicolumn{2}{|c|}{ Set size $(\mathrm{cm}) \mathrm{X}$ no. of rows } & NS & - & 12.1 & * & 16 & 8.5 \\
\hline \multicolumn{2}{|c|}{ Set size $(\mathrm{cm}) \mathrm{X}$ intra-row spacing $(\mathrm{cm})$} & NS & - & & NS & - & \\
\hline \multicolumn{2}{|c|}{ rows ridges ${ }^{-1} \mathrm{X}$ intra-row spacing $(\mathrm{cm})$} & * & 21 & & * & 16 & \\
\hline \multicolumn{2}{|l|}{ All interaction } & NS & & & NS & - & \\
\hline
\end{tabular}

Table 3 Effects of set girth $(\mathrm{cm})$, number of rows ridges $^{-1}$, intra-row spacing $(\mathrm{cm})$ and their interaction on percentage of doubling \% over two seasons

\begin{tabular}{|c|c|c|c|c|c|c|c|}
\hline \multirow{3}{*}{ No. of rows ridges } & \multirow{3}{*}{$\begin{array}{l}\text { Intra-row } \\
\text { spacing }(\mathrm{cm})\end{array}$} & \multicolumn{3}{|c|}{ Season one } & \multicolumn{3}{|c|}{ Season two } \\
\hline & & \multicolumn{6}{|c|}{ Bulb set girth (cm) } \\
\hline & & $2-3$ & $1-2$ & Mean & $2-3$ & $1-2$ & Mean \\
\hline \multirow[t]{2}{*}{2} & 7.5 & 14.3 & 1.3 & 7.8 & 11.9 & 0.4 & 6.2 \\
\hline & 10 & 16.8 & 2.5 & 9.7 & 9.2 & 0.0 & 4.6 \\
\hline Sp. mean & & 15.6 & 1.9 & 8.8 & 10.5 & 0.2 & 5.4 \\
\hline \multirow[t]{2}{*}{3} & 7.5 & 15.3 & 1.5 & 8.4 & 14.0 & 0.9 & 7.4 \\
\hline & 10 & 13.3 & 3.5 & 8.4 & 8.0 & 0.0 & 4.0 \\
\hline Sp. mean & & 14.3 & 2.5 & 8.4 & 11.0 & 0.4 & 5.7 \\
\hline Mean & & 14.9 & 2.2 & 8.6 & 11.9 & 0.4 & 5.6 \\
\hline \multicolumn{8}{|c|}{ Statistics } \\
\hline & & Sig. & & $\mathrm{CV} \%$ & Sig. & $\mathrm{SE} \pm$ & $\mathrm{CV} \%$ \\
\hline \multicolumn{2}{|l|}{ Set size $(\mathrm{cm})$} & $* * *$ & & & $* * *$ & 0.3 & \\
\hline \multicolumn{2}{|l|}{ rows ridges ${ }^{-1}$} & NS & & & $* * *$ & 0.3 & \\
\hline \multicolumn{2}{|c|}{ intra-row spacing $(\mathrm{cm})$} & $*$ & & & NS & - & \\
\hline \multicolumn{2}{|c|}{ Set size $(\mathrm{cm}) \mathrm{X}$ no. of rows } & $*$ & & 6.9 & NS & - & 17.3 \\
\hline \multicolumn{2}{|c|}{ Set size $(\mathrm{cm}) \mathrm{X}$ intra-row spacing $(\mathrm{cm})$} & $*$ & & & NS & - & \\
\hline \multicolumn{2}{|c|}{ rows ridges ${ }^{-1} \mathrm{X}$ intra-row spacing $(\mathrm{cm})$} & $*$ & & & * & 0.4 & \\
\hline \multicolumn{2}{|l|}{ All interaction } & NS & & & NS & - & \\
\hline
\end{tabular}


Table 4 Effects of set girth $(\mathrm{cm})$, number of rows ridges ${ }^{-1}$, intra-row spacing $(\mathrm{cm})$ and their interaction on mean pulp girth $(\mathrm{cm})$ over two seasons

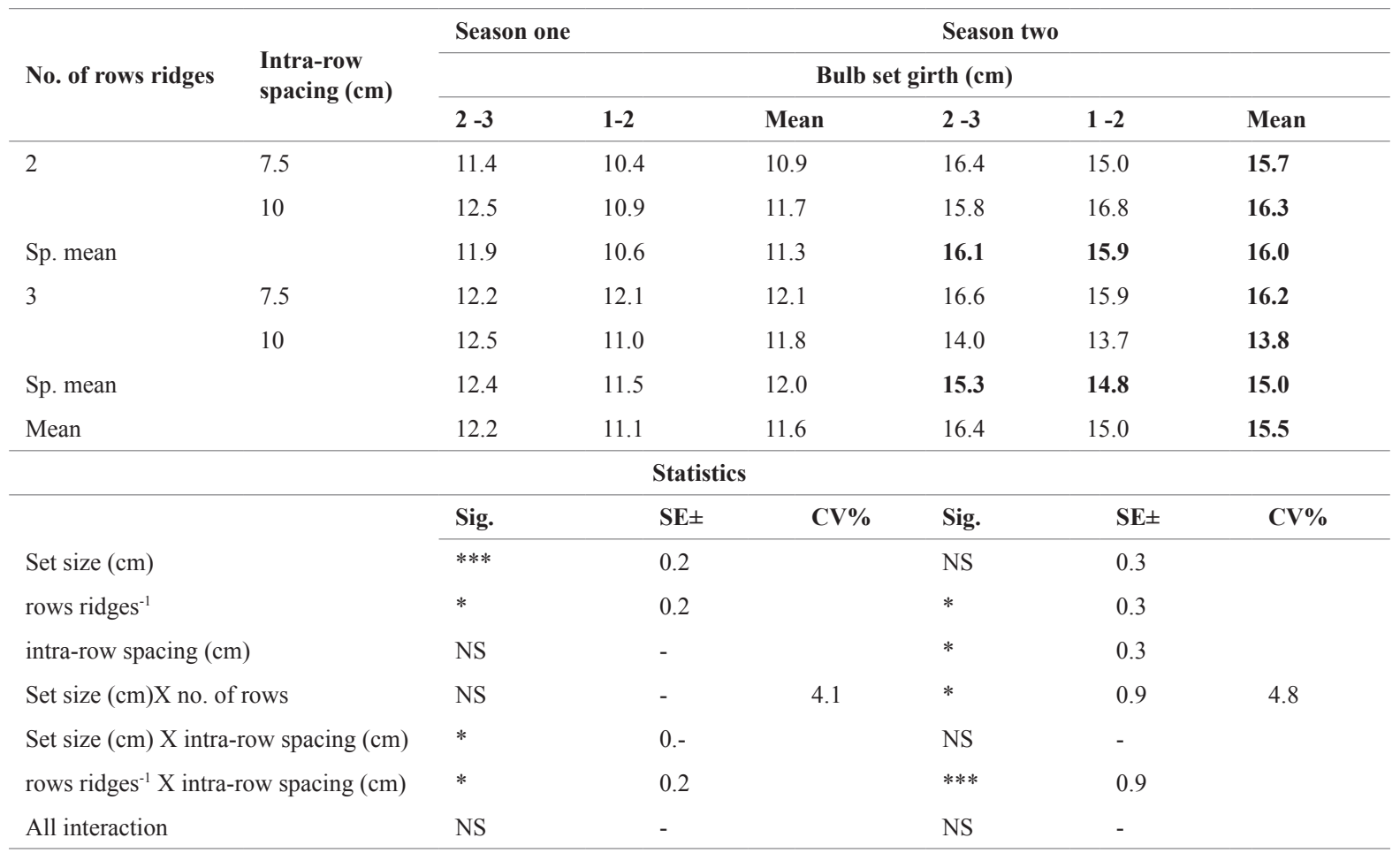

Table 5 Effects of set girth $(\mathrm{cm})$, number of rows ridges ${ }^{-1}$, intra-row spacing $(\mathrm{cm})$ and their interaction on yield tons ha- ${ }^{-1}$ over two seasons

\begin{tabular}{|c|c|c|c|c|c|c|c|}
\hline \multirow{3}{*}{ No. of rows ridges } & \multirow{3}{*}{$\begin{array}{l}\text { Intra-row } \\
\text { spacing }(\mathrm{cm})\end{array}$} & \multicolumn{3}{|c|}{ Season one } & \multicolumn{3}{|c|}{ Season two } \\
\hline & & \multicolumn{6}{|c|}{ Bulb set girth $(\mathrm{cm})$} \\
\hline & & $2-3$ & $1-2$ & Mean & $2-3$ & $1-2$ & Mean \\
\hline \multirow[t]{2}{*}{2} & 7.5 & 8.6 & 7.8 & 8.2 & 17.4 & 15.5 & 16.5 \\
\hline & 10 & 7.5 & 9.4 & 8.4 & 16.6 & 16.2 & 16.4 \\
\hline Sp. mean & & 9.7 & 6.3 & 8.0 & 18.2 & 14.9 & 16.5 \\
\hline \multirow[t]{2}{*}{3} & 7.5 & 16.1 & 8.9 & 12.5 & 18.4 & 15.3 & 16.9 \\
\hline & 10 & 20.8 & 12.5 & 16.7 & 21.8 & 14.5 & 18.1 \\
\hline Sp. mean & & 11.4 & 5.2 & 8.3 & 15.1 & 16.1 & 15.6 \\
\hline Mean & & 12.4 & 8.3 & 10.3 & 17.9 & 15.4 & 16.7 \\
\hline \multicolumn{8}{|c|}{ Statistics } \\
\hline & & Sig. & & $\mathrm{CV} \%$ & Sig. & $\mathrm{SE} \pm$ & $\mathrm{CV} \%$ \\
\hline \multicolumn{2}{|l|}{ Set size $(\mathrm{cm})$} & $* * *$ & & & $* * *$ & 0.2 & \\
\hline \multicolumn{2}{|l|}{ rows ridges $^{-1}$} & $* * *$ & & & NS & - & \\
\hline \multicolumn{2}{|c|}{ intra-row spacing $(\mathrm{cm})$} & $* * *$ & & & * & 0.4 & \\
\hline \multicolumn{2}{|c|}{ Set size $(\mathrm{cm}) X$ no. of rows } & $* * *$ & & 4.6 & $* * *$ & 0.3 & 3.1 \\
\hline \multicolumn{2}{|c|}{ Set size $(\mathrm{cm}) \mathrm{X}$ intra-row spacing $(\mathrm{cm})$} & NS & & & $* * *$ & 0.3 & \\
\hline \multicolumn{2}{|c|}{ rows ridges ${ }^{-1} \mathrm{X}$ intra-row spacing $(\mathrm{cm})$} & $* * *$ & & & $* * *$ & 0.4 & \\
\hline \multicolumn{2}{|l|}{ All interaction } & * & & & * & 0.4 & \\
\hline
\end{tabular}

\section{Discussion}

The greatest plant height was obtained by three rows ridges ${ }^{-1}$ in both seasons, that mien increase plants population increase plant height In agreement to current finding, Aliyu et al. ${ }^{11}$ also found superior plant height at $25 \mathrm{~cm}$ intra-row spacing than at $15 \mathrm{~cm}$ intra-row spacing
The set girth $(2-3 \mathrm{~cm})$ produced high Percentage of doubling \%, This in agreement with Matimati et al. ${ }^{12}$ also showed that large sets produced triple, bulbs with a weight comparable with small sets. The greatest yield tons $\mathrm{ha}^{-1}$ was obtained by large set, the current result is in agreement with Naser AA et al. ${ }^{13}$ recorded the large set produced heavier bulbs than the small set. The greatest yield tons ha ${ }^{-1}$ was 
obtained when grown at $10 \mathrm{~cm}$ intra-row spacing three rows ridges ${ }^{-1}$ in both seasons. The current result is in agreement with Jan et al. ${ }^{14}$ recorded the highest yield (40.44 t/ha) at spacing of $17 \times 4.5 \mathrm{~cm}$, while the lowest yield (19.95 t/ha) at $27 \times 14.5 \mathrm{~cm}$ spacing.

\section{Conclusion}

According to these result presented it is suggested that used set girth $(2-3 \mathrm{~cm})$ growing at $10 \mathrm{~cm}$ intra-row spacing three rows ridges ${ }^{-1}$ would yield appropriate production green bunch onion under rain fed conditions in Blue Nile state, Sudan.

\section{Acknowledgments}

None.

\section{Conflicts of interest}

Authors declare that there is no conflicts of interest.

\section{References}

1. Kukanoor 1. Post-harvest studies in onion cv. Thesis University of Agricultural Sciences, Dharwad, India; 2005.

2. Shaheen AM, Rizk FA, Abdel-Aal FS, et al. Production of safe and economic onion bulbs. International Journal of Academic Research. 2011;3(1):527-532.

3. Raj N, Yadav DS. Advances in vegetable production, New delhi research co. book centre. 2005;995.

4. Moard. Crop variety register. Crop development department, Addis Abeba, Ethiopia; 2006:(9).
5. Rabinowith HD, Currah L. Allium crop science, CABI, Wallingford, UK; 2002:544.

6. Abdelaziz HH. Economics of onion production in northern part of omdorman province, khartoum State. Albuhuth. 2008;12(1):42-51.

7. Yamaguchi M. World vegetables, principles, productions and nutritive Values, University of california, Davis, California, 1980;187-188.

8. Lemma D, Shimeles A. Research experiences in onion sproduction. Research report No. 55, EARO, Addis Abeba Ethiopia;2003;52.

9. Geremew A, Teshome A, Kasaye T, et al. Effect of intra-row spacing on yield of three onion (Allium cepa 1.) varieties at Adami Tulu agricultural research center (mid rift valley of Ethiopia). J Horticulture Forestry. 2010;2(1):007-011,

10. Buysse W, R Stern, R Coe. Gen stat discovery edition for everyday use. ICRAF Nirobi, Kenya. 2004;114.

11. Aliyu U, Dikko AU, Magaji MD, et al. Nitrogen and intra-row spacing effect on growth and yield of onion (AlliumcepaL.,). J Plant Sci. 2008;3(3):188-193.

12. Matimati I, Murungu FS, Handiseni M, et al. Effect of set size and cultivar on marketable yield of onion (Allium cepa). Journal of New Seeds. 2006;8(1):61-70.

13. Naser AA, Jaime A. Teixeira da silva and najmeh yazdani. effect of onion set size and cultivar on production of green bunch onion (Allium cepa). Middle Eastern and Russian Journal of Plant Science and Biotechnology. 2009;5-9.

14. Jan NE, Wazir FK, Ibrar M, et al. Effect of different inter and intra-row spacing on the growth and yield of different cultivars of onion. Sarhad J Agric. 2003;19:4. 